\title{
How Marston Read His Merchant: Ruled Women and Structures of Circulation in The Dutch Courtesan
}

\begin{abstract}
This essay argues that The Merchant of Venice was highly influential on John Marston's The Dutch Courtesan, guiding the changes Marston made to his source text. Marston extends Merchant's critiques of nascent capitalism and is especially critical of the commodifying male sexuality embodied by Freevill and influenced by the characterizations of Portia and Bassanio. Recognizing Courtesan's debts to Merchant also enables a better understanding of how Marston's move to the Children of the Queen's Revels affected his dramaturgy. By showing how Freevill self-consciously and inauthentically performs the role of a romance hero, Marston participates in the company's characteristic ironizing of romance.
\end{abstract}

Much like the rest of John Marston's œuvre, The Dutch Courtesan owes considerable debts to a variety of Shakespeare plays. ${ }^{1}$ Perhaps the most obvious influence is Much Ado About Nothing (1598-9), as Crispinella reminds us of Much Ado's Beatrice, and thus Crispinella's courtship with Tisefew becomes an echo of Beatrice's merry war with Benedick. Similarly, Marston's patiently suffering Beatrice and callous Freevill take on shades of Hero and Claudio, and the bumbling constables who apprehend Mulligrub recall Dogberry and his men. ${ }^{2}$ Looking beyond Much Ado, Malheureux is a 'man of snow' very much like Angelo in Measure for Measure, which one editor has called 'a companion piece' to Courtesan (2.1.83); 3 Freevill and Beatrice's balcony scene is reminiscent of Romeo and Juliet, as is Nurse Putifer; and we can see shades of Twelfth Night in Cocledemoy's assumption of a fake persona to torment the innocent Mulligrub, whom he has had imprisoned as part of a trick, and perhaps even Othello, in Franceschina's refusal to speak as she is hauled away for punishment at play's end. ${ }^{4}$ Thus, like many Marston plays, and appropriately given its depiction of London as a cosmopolitan centre of trade,

Meghan C. Andrews (andrews@lycoming.edu) is assistant professor of English at Lycoming College, Williamsport, PA. 
Courtesan teems with Shakespearean wares, fusing them to create Marston's own new and unique commodity.

One Shakespeare play that has never been substantively connected to Courtesan, however, is The Merchant of Venice, a play that perhaps not coincidentally was performed twice at court in front of King James in February 1605. In fact, studies of Marston's drama rarely mention Merchant at all, even though the murderous usurer Mammon in Jack Drum's Entertainment (1599) is a clear parody of Shylock. Merchant's omission from discussions of The Dutch Courtesan is particularly striking given that the plays share significant similarities. Most notably, both see a resident alien in a metropolis, who has schemed to take the life of a citizen after being wronged by that citizen, turned into a scapegoat by play's end. Both Franceschina and Shylock are punished by the legal system for their crimes but also become figures onto whom the play's citizens project their own failings, a repository for society's disavowed and abjected energies. ${ }^{6}$

But the similarities extend beyond the plays' parallel examinations of xenophobia. This essay argues that The Merchant of Venice had a much stronger influence than has been recognized on The Dutch Courtesan's critiques of the commodification of individuals in a nascently capitalist society as well as the sexual morals and conduct of fashionable young gentlemen, and especially how the former informs the latter. Courtesan extends Merchant's concerns about confusion between purse and person; if Merchant reflects a culture undergoing a transition to capitalism and uneasy about the implications of this shift, Courtesan depicts a world in which that transition is complete and everything — including humans - are commodities in an open market, especially in the eyes of voracious young gallants. Courtesan, like Merchant, is critical of this new world, and Marston's play uses and amplifies narrative elements taken from Merchant to make its critiques. Marston accomplishes this work largely through the character of Freevill, who becomes a kind of bastard child of Bassanio and Portia as the play goes on, merging more extreme versions of Bassanio's mercenary attitude toward sexuality with Portia's manipulations of and control over the bodies of others. Understanding how Marston read Merchant thus gives us a better understanding of Courtesan itself as well as how Marston's mid-career move to the Children of the Queen's Revels affected his dramaturgy and helped shape the second half of his career.

\section{Free Will Unfettered}

Since the publication of John J. O'Connor's 'The Chief Source of Marston's Dutch Courtezan', critics have widely acknowledged that Marston's primary narrative 
source for Courtesan was Nicholas de Montreux's Le premier livre des bergeries de Julliette (1585), a French romance never translated into English. ${ }^{7}$ Marston found in the inset story of Dellio (Freevill), Cinthye (Franceschina), the Sieur de la Selve (Malheureux), and Angelicque (Beatrice) a plot he followed almost entirely faithfully, though his thematic concerns are very different from Montreux's focus on male friendship, honour, virtue, and love. Much more like Merchant as well as other early city comedies, Courtesan takes a searing look at not only xenophobia but also the collision of capitalism and communities, and especially vulnerable individuals — vulnerable bodies — in those communities. Shakespeare's play shows significant reservations about the social effects of the nascent cultural transition to capitalism, and specifically the dehumanization and commodification of human beings this commercial system entailed. When a pound of Antonio's flesh is worth 3,000 ducats, when Shylock confuses his ducats with his daughter, and when Bassanio's affection for both Antonio and Portia seems inextricably tied to their finances, Shakespeare shows the dangers of confusing purse and person. Courtesan, while it possesses the same anxieties, portrays a world in which this cultural transition is a fait accompli. In Marston's play, we are fully immersed in a world in which everything, including human bodies, can be bought and paid for, and one in which all of the characters unquestioningly acknowledge that reality of the game. ${ }^{8}$

Perhaps the most adroit player of the game is Freevill, who, as O'Connor notes, is very different from the generally honourable, well-intentioned Dellio of Les bergeries. ${ }^{9}$ Dellio is genuinely infatuated with the courtesan Cinthye, but Freevill sees Franceschina as little more than a convenient outlet for his lust, and the play raises questions about his attitude toward Beatrice as well. In consistently using language that dehumanizes and demeans Franceschina even as he pays her for sex, giving an encomium to prostitution, or going directly from being serenaded by his courtesan to serenading his fiancée, Freevill reveals his perception of a fundamental link between sexuality and money as well as the transactional nature of sexuality more broadly, an attitude nowhere present in Dellio. This confusion of purse and person makes Freevill more reminiscent of Bassanio, whose affection for Portia and Antonio both is suspect insofar as it seems premised on their financial support. Bassanio is not nearly as extreme in his misogyny or commodifying impulse as is Freevill, and the ways in which Bassanio and Freevill intertwine sex and money are oriented differently - Freevill seems to see money as a way to get sex, while for Bassanio sex is a way to get money ${ }^{10}$ — but the seeds of Freevill's attitude are present in Bassanio. 
Bassanio's influence on the character of Freevill, however, is most obvious in the rings plot, for one of the greatest continuities between Merchant and Courtesan is the circulation of, and significance invested in, the main couple's rings. To be sure, a ring does feature in Les bergeries, as Cinthye asks the newly-engaged Dellio for a ring Angelicque has given him; he refuses, but then loans it to the Sieur de la Selve so that the Sieur can swear to have killed him and thus have sex with Cinthye. But while Marston follows his source text faithfully in the first half of Courtesan, we can discern Merchant's influence in several smaller changes he makes to Montreux. First, Beatrice's gift of her ring to Freevill mirrors Portia giving her ring to Bassanio. In Les bergeries, while the ring is symbolic of their love and engagement, Dellio and Angelicque invest it with no significance beyond the obvious. Even the gifting of the ring is a quick affair, as the text simply states 'Angelicque gave an elegant ring to Dellyo, which he valued with his life, so much was the devotion he had for her'; 11 later the text also states that 'he held it more dear than his own eyes because it was Angelicque who had given it to him as a foundation and plan for their love', and later still a taunting Cinthye says to Angelicque that Dellio 'promised you to hold [it] more dear than his own heart'. While the ring is clearly important to Dellio, it holds no meaning other than as a symbol of his devotion to and love for Angelicque.

In contrast, when Beatrice gifts Freevill a ring in 2.1, she invests it with emotional significance beyond its status as a token of their upcoming engagement:

BEATRICE Dear my loved heart, be not so passionate.

Nothing extreme lives long. FREEVILL

But not to be extreme!

Nothing in love's extreme; my love receives no mean.

BEATRICE I give you faith and, prithee, since, poor soul,

I am so easy to believe thee,

Make it much more pity to deceive me.

Wear this slight favour in my remembrance.

Throweth down a ring to him.

FREEVILL Which, when I part from, hope - the best of life - ever part from me.

BEATRICE I take you and your word, which may ever live your servant. 
When she gives her ring to Freevill, Beatrice makes it a token of not only their love but more specifically her belief in Freevill's vow of constancy in love. In this it mirrors Portia gifting her ring to Bassanio: ${ }^{12}$

PORTIA This house, these servants and this same myself, Are yours, my lord's. I give them with this ring Which, when you part from, lose or give away, Let it presage the ruin of your love, And be my vantage to exclaim on you.

BASSANIO But when this ring

Parts from this finger, then parts life from hence;

O, then be bold to say, 'Bassanio's dead.'

Both Portia and Beatrice make their ring symbolic not only of their impending nuptials but also of their trust in their fiancés' emotional fidelity. Portia is more pessimistic than is Beatrice — she couches Bassanio's imagined betrayal as a 'when' in contrast to Beatrice's 'if', and more explicitly places conditions upon Bassanio's possession of the ring — but both women make the ring a token of their faith in their lover's emotional commitment. And Freevill and Bassanio have identical responses, both swearing that the rings will be taken over (or from) their dead bodies, setting their love above life itself.

And, of course, neither man holds to his vow. Both Bassanio and Freevill rebuff a first request for their ring but eventually give it to another man (or, in Bassanio's case, what he thinks is another man) for the sake of their best friend, which in both plays is a devastating commentary on the relative lack of importance heterosexual romantic relationships hold relative to male homosocial relationships. ${ }^{13}$ But if Bassanio is reluctant to give up his ring, Freevill is all too willing. ${ }^{14}$ Twice he shows no hesitation in giving Malheureux the ring, first in his initial concoction of the plan, when Freevill states, 'this ring only lent ... Then, to thy wench; protest me surely dead, / Show her this ring, enjoy her, and, blood cold, / We'll laugh at folly' (3.1.274-82). An act later he shows that same lack of hesitation when he actually gives the ring to Malheureux, saying again:

I'll lend this ring. Show it to that fair devil.

It will resolve me dead;

Which rumour, with my artificial absence,

Will make most firm — Enjoy her, suddenly. 
In fact, unlike Bassanio, Freevill does not even have to be asked to give up his ring; twice he offers it freely, and never displays any of the reluctance that either Dellio or Bassanio do when he hands it over, showing no regard for his broken vow. Worse still, Freevill's words and actions reduce the ring to a token not of love but of sex, devaluing his relationship with Beatrice and implicating her in the game of sexual circulation played in London that has very little to do with love. ${ }^{15}$ A further Marstonian addition to Montreux - the ring subplot with Crispinella, Tisefew, and Caqueteur, which mirrors the main plot just as Gratiano and Nerissa's ring mirrors Portia and Bassanio's - only reinforces this connection, emphasizing that for gallants, rings are currency in a homosocial world of circulation and that they will lie outrageously about them to women. As Caqueteur's feelings for Crispinella seem not to be truly authentic, the subplot again casts rings as tokens of sex, not love, emphasizing Freevill's devaluation of Beatrice's gift.

Marston's additions and changes to the rings plot provided in Les bergeries thus take their cue from Merchant and emphasize Freevill's faithlessness and transactional attitude toward sexuality. In investing Beatrice and Freevill's ring with the kind of symbolic value invested in Portia and Bassanio's ring, Marston makes Freevill's loan of the ring to Malheureux a worse version of Bassanio's emotional betrayal, both because Freevill offers his ring freely while Bassanio is reluctant to give his up and because Bassanio relinquishes the ring in thanks for a life saved while Freevill offers it for the baser purpose of (supposedly) enabling Malheureux to have sex with Franceschina. The changes Marston makes to the ring plot in Courtesan's first half make Freevill into a worse version of Bassanio, making more pronounced Bassanio's flaws and opening them up to sharper critique.

But the moment in which Freevill loans Malheureux his ring is important in another way, as it also marks Marston's greatest deviation from his source text as well as the point at which Freevill begins to take on Portia's worst qualities in addition to Bassanio's. In Les bergeries, Dellio does not double-cross the Sieur as Freevill does Malheureux. Instead, the plot to enable the Sieur to have sex with Cinthye is played straight. Dellio, genuine in his desire to help the Sieur win Cinthye, gives him the ring and hides in the countryside to fake his own death. The Sieur comes to Cinthye claiming to have killed Dellio, she promptly alerts the authorities, and he is apprehended in her chambers and imprisoned. Cinthye, meanwhile, takes Dellio's ring to a distraught Angelicque, leaving it with her along with taunts about how Dellio never loved her. The Sieur is only saved from death because Dellio fears something has gone awry and returns to Venice the night before the Sieur is scheduled to be executed. He learns of the impending execution 
and reveals himself in the courtroom the next day, saving his friend. Dellio then goes to Angelicque's house, where she lies in a deathlike state thanks to a broken heart, and his presence revives her. After some recriminations on her part, the lovers are reunited and live happily ever after, while Cinthye leaves Venice in bitterness and the Sieur departs because Venice has been bitter to him.

In other words, Freevill's disguise, subsequent betrayal of and orchestration of a near-death experience for Malheureux, return of the ring to Beatrice in person, and manipulation of the rest of the characters stands as Marston's most radical change to his source text. Marston had good dramaturgical reasons to make these changes; keeping Freevill, probably played by the company's leading actor, offstage and passive for the entire last two acts is far less dramatically compelling than allowing him to be the disguised orchestrator of the play's denouement. Similarly, allowing Freevill to be the character who saves Beatrice by returning the ring to her is a powerful and dramatically economical move that enables Freevill and Beatrice to reunite before the final scene and therefore allows the play to end with his triumphant overthrow of Franceschina and saving of Malheureux. These changes perhaps remind us of Measure, which similarly ends with a disguised male manipulator revealing himself after appearing to double-cross a wrongfullyaccused party, ultimately vindicating said wrongfully-accused party and punishing the play's duplicitous villain in what had been the villain's moment of triumph. But Courtesan's changes to the ring plot also create similarities between Freevill and Shakespeare's Portia, who is also given a great deal of control over the bodies and sexualities of her play's other characters. Like Portia, Freevill takes on a disguise to help someone he loves, testing Beatrice's love and loyalty in the process just as Portia tests Bassanio's, and uses his disguise to save a wronged citizen (Malheureux) from the imminent threat of death, re-acquiring his own wayward ring along the way - a ring whose waywardness signifies a broken oath to a female partner. Also like Portia, Freevill is involved with the near-execution of that same wronged citizen, thwarting it only at the last second with xenophobic machinations that scapegoat and sentence a resident alien, Franceschina, ostensibly punishing her for a crime against Malheureux even as the metropolis projects all its worst qualities onto her - just as, in Merchant, Portia saves Antonio by scapegoating Shylock, onto whom the Venetians similarly project their city's worst qualities. Especially as Marston not only has changed the resident foreigner from the Sieur in Montreux to Franceschina in Courtesan, but also has imposed on Franceschina a far heavier punishment than is received by Cinthye, who simply leaves Venice of her own accord, the influence of Merchant is strongly felt in Courtesan's final scene. 
Further, and perhaps unfairly given Courtesan's events but again like Portia, by the play's end Freevill has solidified his position as the dominant partner in his relationship with Beatrice just as Portia cements herself as her relationship's dominant partner in yet another subsidiary change Marston made to Montreux. As noted above, in Les bergeries Angelicque ends the narrative in possession of her ring, symbolizing her equal status with Dellio. The ring is passed to her by a taunting Cinthye, but Angelicque does not return the ring to Dellio at their reunion; she only mentions it as part of a more general reproach to him, believing that Dellio gave the ring to Cinthye to signify his lack of love for her. Dellio, while defensive about the fact that he did not give the ring to Cinthye and thus feeling unjustly accused, nevertheless is willing to kill himself to show his devotion to Angelicque and clear his name. She stops him and the two are reconciled. In Courtesan, on the other hand, Freevill ends the play with the ring in his possession and without having truly apologized to Beatrice for his misdeeds or having repented. Angelicque's possession of her ring at her narrative's end signifies that she has been wronged by Dellio, and is metonymic of her control over herself and the need for Dellio to make amends before they can be reunited, whereas in Courtesan Freevill's possession of the ring signifies that all of his plots have come successfully to fruition and that his control over the heretofore passive, subservient Beatrice is complete without any need for penance. Tellingly, the ring drops entirely out of the reunion scene in Courtesan, not mentioned in dialogue nor in the stage directions (though much could be done with the ring in performance). And the ring is not the only thing to be lost in the transition between texts, as alongside it, Angelicque's face-to-face recriminations also do not make it into Marston's play. Beatrice is given neither the opportunity nor the inclination to air what would be well-deserved grievances against Freevill, though we have seen her offer gentle rebukes earlier. Instead, Crispinella gets a single line of chastisement against Freevill — 'Brother, I must be plain with you: you have wronged us' only to be quickly brushed aside by Freevill:

I am not so covetous to deny it,

But yet, when my discourse hath stayed your quaking

You will be mild and quiet, forget at last.

It is much joy to think on sorrows past.

As Keith Sturgess observes, Freevill 'can slide (Marston lets him)' from facing real consequences for his actions. ${ }^{16}$ 
If, like Bassanio, Freevill has broken faith with his fiancée, his dominant position in his relationship with Beatrice nevertheless casts him as Portia, which emblematizes the gender roles Courtesan seeks to critique. In Merchant, as Karen Newman has argued in an article that helped give this essay its title, Portia's acquisition of the ring and then ostentatious return of it to Bassanio via Antonio with a short-lived lie about having slept with 'Balthazar' is a power move that bucks patriarchal trends by empowering a woman. ${ }^{17}$ Giving Bassanio the ring back signals both that Bassanio and Antonio are newly indebted to Portia and that she knows about Bassanio's broken vow and thus would be justified (if so inclined) to repay it with one of her own. Her return of the ring is a move that humbles Bassanio, placing Portia in control. In Courtesan, on the other hand, Freevill is always on top; his possession of the ring at play's end signifies this position, and is indicative of a sharp difference between the two plays' gender politics — one designed, again, to link the commodification of individuals with Freevill's particularly predatory brand of male sexuality. ${ }^{18}$ Freevill is thus the character through which Marston links the commodification of humans much more tightly than did Shakespeare to an unsettling male attitude toward sexuality that sees women as objects, not people. Freevill becomes a more extreme version of both Bassanio and Portia, merging their worst qualities to invite questions about his conduct and 'mak[e] it evident that he and the social values he ultimately represents are open to sharp scrutiny'. 19

Marston's critique of Freevill, however, does not mean that his ideas regarding women were particularly progressive. The play strongly supports Beatrice's model of patiently suffering femininity, and that the 'Kill Claudio' scene of Much Ado is given to Franceschina and Malheureux instead of to Crispinella and Tisefew, Beatrice and Benedick's spiritual descendants, signals that Courtesan sees female sexuality as fundamentally dangerous. The play's sympathies are often with its women, as Courtesan shares with Much Ado the recognitions that male homosociality is almost always bad for women and that early modern women were societally restricted such that they needed men to act for them. Nevertheless, that the one moment in Courtesan in which a woman pushes back is a moment of obvious, murderous villainy suggests that female sexuality is a threat, presenting a rival to predatory male sexuality in allowing women to play the game men would prefer to hold as their exclusive preserve. Active female sexuality empowers women, giving them the tools to have power over and manipulate men (which may help explain Freevill's attraction to Beatrice's virginity, as her lack of sexual experience helps ensure his dominance). ${ }^{20}$ For, aside from the plots of Franceschina and her bawd Mary Faugh, female sexuality is either nonexistent or nonthreatening 
in Courtesan; for all of Freevill's valuation of chastity, unlike Much Ado but like Merchant, Courtesan does not feature any male paranoia about female sexuality, founded or otherwise. In fact, the far more paranoid gender in Courtesan, rightly so, is the female, as Beatrice alone asks Freevill four or five times not to toy with her and even Franceschina tests Freevill's fidelity in 2.2, just as Merchant's women are more suspicious of their husbands than vice versa. But if Courtesan has sympathy for women caught in men's manipulations, and if it allows Crispinella a voice with which to sharply criticize male conduct, it nevertheless cannot envision a world in which women have any substantial refuge against male mistreatment. It may be true that both Franceschina and Beatrice 'object to Freevill's easy recourse to totalizing stereotypes of woman-as-deity or woman-as-whore', but on a larger level the play itself reifies a slightly different binary: woman as passive sufferer or active evil. ${ }^{21}$

In so doing, Courtesan offers a pessimistic outlook to London's women, far more pessimistic than the outlook suggested by the endings of Merchant or Much Ado. Unlike Portia, Much Ado's Beatrice, or even Hero, all of whom are empowered in different ways by the end of their respective plays, Courtesan's Beatrice and Franceschina both seem trapped by the men around them into playing their designated roles. Recent critics have also suggested that Crispinella and Tisefew, too, may end the play on an uneasy note that can suggest future discord if Crispinella continues to be independent and outspoken. ${ }^{22}$ If Shakespeare in what we might call his 'suburban' comedies offers a fantasy of at least limited female empowerment against male strictures, Marston offers his heroines no such succor. ${ }^{23}$

\section{Caught in a Bad Romance}

In closing, I want to suggest that understanding Marston's debts to Shakespeare's 'suburban' comedies Merchant and Much Ado helps illuminate the effects of Marston's change in theatrical company on his dramaturgy. Marston began his career writing for the Children of St Paul's, producing Antonio and Mellida, Jack Drum's Entertainment, Antonio's Revenge, and What You Will for them between 1599 and 1601/2. But with The Malcontent (1603/4), he moved to the Children of the Queen's Revels, who performed at the Blackfriars under various names in the first decade of the seventeenth century. At some point, Marston also became a sharer in the Blackfriars company, giving him a vested interest in the company's development and consolidation of its repertoire, potentially also a voice in shaping its repertory. Perhaps for this reason, his move to the Queen's Revels seems to have shifted his vision of comedy as well as his relationship to Shakespeare's texts. 
In her important study of the Queen's Revels, Lucy Munro argues that the company developed a distinct style of comedy that at times defeated generic expectations. Contending that their comedies 'demonstrate a striking awareness of the problematic aspects of comic closure, and the equally problematic relationship between comedy and laughter', as 'jokes often seem to work against narrative structures, complicating or negating comedy's movement towards reconciliation', Munro notes that this approach to comedy also carried over into the company's vision of tragicomedy. ${ }^{24}$ While the King's Men drifted toward Shakespearean romance in their tragicomic plays, Munro argues that the Children of the Queen's Revels embraced a mode better labeled anti-romance, since in their tragicomedies, 'romance is complicated by the introduction of material which reverses, complicates, exaggerates, or, especially, ironises it', a strategy that extended to the company's treatment of biblical or folktale motifs as well (visible in for example Eastward Ho [1605]'s subversion of the prodigal son narrative), as the company staked out a different, more cynical position in London's theatrical marketplace than did Shakespeare's company. ${ }^{25}$ Both of these observations are important for understanding how Marston reworked Shakespearean material to suit the Queen's Revels' style. For - unsurprisingly given its roots in Les bergeries - Courtesan, while among the earliest Jacobean city comedies, also possesses strong affinities to romance and closely related folklore motifs, particularly the story of Patient Griselda. And, perhaps unsurprisingly given the nature of the Queen's Revels' repertory, Courtesan works to complicate the Patient Griselda story in a way that serves the play's larger aim of critiquing male sexuality.

From her very first speech, Beatrice is introduced to the audience as a recognizable version of the wife or fiancée who possesses exemplary loyalty to her husband typical in chivalric romance. In that first speech, it takes Beatrice less than ten lines to tell Freevill 'I am your servant' (2.1.18), and she stresses her maidenly silence, modesty, and general subservience to his will. She calls herself Freevill's servant twice more before his supposed death (at 2.1.58 and 3.1.220), an average of once per scene to that point in the play. This consistent self-identification coupled with her general submission of herself to his will and focus on being properly virtuous all lead the audience to see Beatrice as, if not yet a Patient Griselda figure (though her repeated identification of herself as Freevill's servant is suggestive of that narrative), at least as a version of the unimpeachably loyal and virtuous wives of chivalric romance. ${ }^{26}$ But when false news comes of Freevill's death, Beatrice's status as a Patient Griselda figure becomes sharper given her refusal to hate Franceschina because 'I cannot hate what he affected' (4.4.58-9) as well as her inability to condemn or turn against Freevill for his breach of faith. 
Further, the disguised Freevill wonders at her extreme loyalty in a speech designed to highlight these qualities:

Grief endears love. Heaven, to have such a wife

Is happiness to breed pale envy in the saints!

Thou worthy, dove-like virgin without gall,

Cannot that woman's evil, jealousy,

Despite disgrace - nay, which is worse, contempt -

Once stir thy faith? O Truth, how few sisters has thou?

Dear memory, with what a suffering sweetness, quiet modesty,

Yet deep affection, she received my death!

And then with what a patient, yet oppressed kindness

She took my lewdly intimated wrongs.

$\mathrm{Oh}$, the dearest of heaven! Were there but three

Such women in the world, two might be saved.

Freevill's extended focus on Beatrice's faithfulness, patience, kindness, virtuousness, and loving nature, coupled with his use of religious imagery, 'locates Beatrice in the Patient Grissil tradition of martyred women and wives', as of course does the fact that Beatrice's suffering is an unnecessary result of Freevill's machinations. $^{27}$ As James Simpson observes of the troubling of romance in Chaucer's 'Clerk's Tale', 'in this case the tests that premise return to the aristocratic order are themselves the product of the aristocratic "hero", so much that he ceases to be the hero at all'. ${ }^{28}$ But if Freevill is not the hero of this play, he is also conscious of this fact, and tries to obscure it by writing himself a heroic part.

Like Portia, Freevill is a master player of roles, and throughout the early portions of Courtesan is eager to script for himself the role of a faithful courtly-chivalric lover where Beatrice is concerned. His rhetoric when speaking to her is often in a high, romantic register, glimpsed, for example, in his first extended speech to her during the balcony scene:

Still! My vow is up above me and, like time,

Irrevocable. I am sworn all yours.

No beauty shall untwine our arms, no face

In my eyes can or shall seem fair,

And would to God only to me you might

Seem only fair. Let others disesteem

Your matchless graces, so I might safer seem. 
This courtly lover is not the Freevill who discourses on the advantages of prostitution or who laughingly asks Malheureux 'What news from Babylon? / How does the woman of sin and natural concupiscence?' (3.1.230-1). Freevill in the balcony scene literally writes a different part for himself, but the contrast between this moment and several others points out how constructed, and how inauthentic, this role is. ${ }^{29}$

More generally, when Freevill serenades Beatrice under her window with protestations of devotion and loyalty, when he mock-duels with Malheureux over her, when he fakes his death, and then when he reveals himself first to Beatrice in a pathos-filled reunion scene and then to all the other characters in a dramatic scene of judgment, he self-consciously plays the role of a chivalric romance hero, a loyal partner fighting for his lady's honour and surviving trials only to come back disguised to set the world to rights (and importantly, the circulation of a ring representing a faithful woman is also a classic romance motif). Yet the audience is privy to exactly how much this narrative is scripted, not a reality. Because the audience knows that Freevill has come to serenade Beatrice immediately after being serenaded by Franceschina, that the mock duel over Beatrice's honour is part of a larger sordid plot, that Beatrice has been largely an afterthought to Freevill, whose disguise has not been part of any sort of larger trial or quest, and that Freevill has actually broken faith with his beloved, the audience can clearly see that this identity is nothing more than a performance. And its performative nature is never as obvious as during what ought to be the crowning moment of Freevill's script. When Freevill reveals to Beatrice that he is alive, he begins a self-centred speech - 'Cursed be my indiscreet trials! Oh, my immeasurably loving -', only to be cut off by Crispinella's brutally practical 'She stirs! Give air! She breathes!', which both deflates his romantic beginning and points out how narcissistic Freevill remains (5.2.49-51). Further, as Freevill claims shortly thereafter, 'Nor ever hath my love been false to you; / Only I presumed to try your faith too much, / For which I am most grieved' (5.2.61-3), a clear lie, the play invites the audience to see how hard he is working to perform the role of a faithful romance hero, and how this performance does match the reality of his story. Beatrice is a romance heroine, a Patient Griselda, but Freevill is not an honest, honourable, suffering chivalric hero, and the extent to which he attempts to play this role, as well as the clear contrast with his actual actions, contributes to the critique of his behaviour elucidated above. ${ }^{30}$ Here Marston ironizes the romance elements of his drama in the service of critiquing the very non-romantic actions of and attitudes held by Freevill. 
Further, Munro has also pointed to the undercutting of comic closure as a strategy by which the Queen's Revels did their work, and we can see that openendedness at play in Courtesan as well. If 'Comic narratives tend to stress contrition and reconciliation', Freevill never quite seems repentant, nor does he actually apologize by play's end, placing stress on the comic closure of the play. ${ }^{31}$ That Cocledemoy, whose similarities to Freevill the play takes pains to highlight, also lacks contrition and is barely reconciled to Mulligrub only further unsettles what could otherwise come off as a very generically predictable ending. Munro focuses on the Children of the Queen's Revels' querying of class status when discussing the company's avoidance of closure, but here we see Marston adopting, or perhaps even partly constructing, a familiar Queens Revels strategy to query instead normative heterosexual structures and male behaviour and, instead of its overlap with politics, London's burgeoning capitalism. If for Munro the company's comedies 'actively interrogate the social identities associated with the spectators', Courtesan also queries the morals of the gallants in the audience resembling Freevill. ${ }^{32}$

This questioning represents something of a shift in Marston's larger approach to romance elements in his drama. Antonio and Mellida and Jack Drum's Entertainment are strongly influenced by festive pastoral romance, particularly Sidney's Arcadia, but while romance conventions are parodied in both plays, they also provide each play's affective center, ultimately played straight insofar as each play's main set of lovers ends the play happily together in part thanks to the play's romance elements. In moving companies, Marston also moved from parodying to problematizing romance conventions. Further, in Courtesan, Marston's relatively newfound attention to the societal limitations placed on women, for which he used Shakespeare as a repository of material, can also stand in as a marker of his larger post-1603 shift, both in terms of his overall treatment of gender and in his relationship to Shakespeare's plays. From Histriomastix to What You Will, Marston became increasingly pessimistic about the prospect of virtue, particularly but not exclusively female virtue, and embraced a burgeoning nihilism. Beginning with The Malcontent, however, Marston charted an increasingly optimistic course through the remainder of his career, one that began to believe in the possibility and power of female virtue as well as to be critical of men in a manner not found in Marston's Paul's plays. Aurelia might be evil at The Malcontent's start, but she repents and joins Maria in virtue; Beatrice and Crispinella (the little sister who, unlike Marston's earlier outspoken, witty women descended from Much Ado's Beatrice, is allowed to fall in love and marry) are virtuous, and even Franceschina is not without sympathetic moments; and by Sophonisba, the title character is of course 'the Wonder of Women'. Similarly, the sexual vices of Piero (also 
redeemed) as well as Mendoza, Freevill and Malheureux, and Syphax appear virtually nowhere in Marston's early plays for Paul's. His move to the Queen's Revels thus seems linked for Marston to a fundamental reimagining of gender roles and relations as well as his larger relationship to romance's generic expectations.

The same might be said for Marston's relationship to Shakespeare's plays. His great debt to Hamlet in the second half of his career can sometimes overshadow his other Shakespearean borrowings, but that Marston was particularly attuned to the suburban comedies and Measure for Measure in his plays for the Queen's Revels, particularly their distrust of men and criticism of men's baseless paranoia about female sexual fidelity (or, in the case of Measure, predatory male sexuality), marks a new phase in his borrowing from Shakespeare, one that perhaps better aligns with the Queen's Revels' more caustic, pessimistically satirical repertory style. ${ }^{33}$ Something of a maturation in technique also accompanied this change in attitude. Marston's earlier, more disjunct and parodic Paul's Boys' drama can often read like Marston threw several Shakespeare plays into a blender, but his plays for the Queen's Revels are more coherent, thoughtful, and deliberate in using Shakespearean material. They are less parodic imitation-satires and more reflective engagements with, or commentary on, Shakespeare's plays, though still with elements of parody.

In the words of one editor, The Dutch Courtesan, 'mark[s] a new maturity of outlook in its author, still fascinated by greed and sexual depravity but generous now to accept and allow the imperfectability of human nature, suspicious, moreover, of those with idealist or absolutist claims. ${ }^{34}$ This elegant and accurate description of Marston's maturation in the play lets us see Marston marking for himself a more moderate position as a satirist and social critic than the one he had inhabited during the earlier phase of his career, though he never loses his indebtedness to other dramatists, chief among them Shakespeare. Marston, we might say, goes through a Bassanio-like process of metamorphosis, one that Freevill himself, the protagonist if not the titular character of The Dutch Courtesan, pointedly fails to attain. 


\section{Notes}

I would like to thank Helen Ostovich and Erin Julian for their close attention to an early draft of this essay as well as for their work in directing the 'Strangers and Aliens in London and Toronto' Symposium; the Symposium's other participants; and the two anonymous readers for Early Theatre. I am also very grateful to Andrew Stafford for his translation aid.

1 John Marston, The Dutch Courtesan, ed. Karen Britland (London, 2018). All further references to the play are from this edition.

2 See for example 'Introduction', in The Malcontent and Other Plays, ed. Keith Sturgess (Oxford, 1997), xxiii; 'Introduction', in The Dutch Courtesan, ed. David Crane (London, 1997), xxv-xxvi; and Tom Bishop's discussion of Crispinella in "'La Bella Franceschina" and Other Foreign Names in Marston's Dutch Courtesan' in this same Early Theatre special issue.

3 Malcontent, ed. Sturgess, xxii. The Sieur de la Selve, the Malheureux character in Marston's source (see above), does not share Malheureux's initial aversion to sexuality and women, making it overwhelmingly likely that Marston looked to Measure's Angelo when creating Malheureux.

4 'Introduction', Dutch Courtesan, ed. Britland, 11-12.

5 'Introduction', The Merchant of Venice, ed. John Drakakis (London, 2010), 113. All quotations from Merchant are drawn from this edition.

6 See for example Dutch Courtesan, ed. Crane, xxiii-xxiv.

7 John J. O'Connor, 'The Chief Sources of Marston's Dutch Courtezan', Studies in Philology 54 (1957), 509-15. For a more recent discussion of Marston's use of Montreux, see Britland, Dutch Courtesan, ed. Britland, 12-22.

8 See for example Dutch Courtesan, ed. Britland, 1-4.

9 O'Connor, 'The Chief Sources', 512-15.

10 As opposed to Les bergeries, in which Montreux states that Dellio's parents arranged his match with Angelicque because they were concerned about his affair with Cinthye, Courtesan omits any mention of Freevill's motivation for marrying Beatrice. The perhaps-unintentional suggestiveness of his language in 2.1 as well as the half-heard sonnet he sends Beatrice in 3.1 may, however, indicate that he is attracted to her virginity and purity above all else.

11 I am deeply indebted to Andrew Stafford for his translation of Montreux, from which I have taken all my quotations (private correspondence).

12 Britland also notes the similarity between the exchange of rings in Merchant and Courtesan at 2.1.55-6n. She detects more sentence-level echoes of Merchant at 
3.2.3-6 in Garnish's 'Your bill had been sufficient - you're a good man' (Dutch Courtesan, 3.2.3-4), which repeats Shylock and Bassanio's confusion over what it means that Antonio is good in Merchant 1.3, and Mistress Mulligrub's 'give me very good words and a piece of flesh when time of year serves' (Dutch Courtesan, 3.3.256), which she sees as influenced by Antonio and Shylock's original agreement to the bond in that same scene. Perhaps not coincidentally, these moments in both plays also involve confusion between the moral and the commercial, the human and the commodity.

13 Susan Baker, 'Sex and Marriage in The Dutch Courtesan', in In Another Country: Feminist Perspectives on Renaissance Drama, ed. Dorothea Kehler and Susan Baker (Metuchen, NJ, 1991), 218-32. Baker suggests that relative to Montreux, the fact that Courtesan's 'theme of friendship is sharply subordinated ... perhaps signals some shift of men's emotional investment to wives rather than friends' (223). But that both Bassanio and Freevill betray those wives in favour of friends is suggestive.

14 In this Bassanio is more like Dellio, who says, 'I will give you the ring that she requested, as a sign of my death, despite how dear it is to me because of who gave it to me. Because I would rather lose not just this jewel but all the riches I have on this earth, than lose a friend that I value so much', as the Sieur intends to leave Venice rather than kill Dellio or live without Cinthye.

15 Garrett A. Sullivan Jr, in "All Thinges Come into Commerce”: Women, Household Labor, and the Spaces of Marston's The Dutch Courtesan', Renaissance Drama 27 (1996), 19-46, https://doi.org/10.1086/rd.27.41917326, argues that the play is anxious about the circulation of Beatrice and works to remove her from the market. I would note that Freevill himself puts her into circulation, however much he also might have anxieties about this circulation.

16 Malcontent, ed. Sturgess, xxiii.

17 Karen Newman, 'Portia's Ring: Unruly Women and Structures of Exchange in The Merchant of Venice', Shakespeare Quarterly 38 (1987), 19-33, https://doi. org/10.2307/2870399.

18 For the play as a critique of masculinity, see for example Kate Aughterson, "Going the Way of All Flesh": Masculinity as Vice in The Dutch Courtesan', Cahiers Élisabéthains 76 (2009), 21-33, https://doi.org/10.7227/ce.76.1.4, and Sarah K. Scott, 'Discovering the Sins of the Cellar in The Dutch Courtesan: Turpe Est Difficiles Habere Nugas', Medieval and Renaissance Drama in England 26 (2013), 60-74.

19 William M. Hamlin, 'Common Customers in Marston's Dutch Courtesan and Florio's Montaigne', Studies in English Literature, 1500-1800 52 (2012), 419, https://doi. org/10.1353/sel.2012.0015. 
20 See also Catherine Belsey, The Subject of Tragedy: Identity \& Difference in Renaissance Drama (London, 1985), 164-7, https://doi.org/10.4324/9781315794419.

21 Baker, 'Sex and Marriage', 226.

22 See for example Helen Ostovich, 'Marriage in The Dutch Courtesan', The Dutch Courtesan, ed. Michael Cordner (2013), http://www.dutchcourtesan.co.uk/marriage -the-dutch-courtesan/.

23 I use 'suburban' comedies to designate Merchant, Much Ado, and Merry Wives as transitional plays between the high romantic festive comedies of the early and mid1590 s and the satirically-inflected Poets' War comedies that lead into the problem comedies.

24 Lucy Munro, Children of the Queen's Revels: A Jacobean Theatre Repertory (Cambridge, 2005), 87, 59, https://doi.org/10.1017/cbo9780511486067.

25 Ibid, 106.

26 On female heroines in romance, see for example Helen Cooper, The English Romance in Time: Transforming Motifs from Geoffrey of Monmouth to the Death of Shakespeare (Oxford, 2004), 218-323. Cooper notes the closeness of the Patient Griselda folktale to the calumniated woman tradition (276-7).

27 Dutch Courtesan, ed. Britland, 4.4.89-100n.

28 Jonathan Bate, ed., The Oxford English Literary History, 13 vols, James Simpson, 1350-1547: Reform and Cultural Revolution (Oxford, 2002), 2.318-19.

29 Munro notes that in Queen's Revels plays, changes in linguistic registers indicate how easily characters can shift in and out of constructed, non-authentic roles (Children of the Queen's Revels, 76-82).

30 Perhaps not coincidentally, Merchant similarly strives to cast Bassanio as an epic hero through, for example, repeated comparisons of Bassanio to Jason.

31 Munro, Children of the Queen's Revels, 95.

32 Ibid, 66.

33 Andrew Gurr, for example, observes that in the theatrical marketplace of the first decade of the seventeenth century, 'The position of Shakespeare's company might more fairly be seen as a neutral one between the polarised Blackfriars and the citizen companies, with Paul's uneasily balanced somewhere between the other hall company and Shakespeare's, and shifting towards the citizen side as time went on'. Playgoing in Shakespeare's London, 2nd ed. (Cambridge, 1996), 161.

34 Malcontent, ed. Sturgess, xxii. 